\title{
The potential of Acmella oleracea (Jambu) extract in the control of semi-engorged Rhipicephalus sanguineus (Latreille, 1806) (Acari: Ixodidae) female ticks
}

Patrícia Rosa de Oliveira, Luis Adriano Anholeto, Rodney Alexandre Ferreira Rodrigues, Gervásio Henrique Bechara, Karina Neoob de Carvalho Castro \& Maria Izabel Camargo Mathias

To cite this article: Patrícia Rosa de Oliveira, Luis Adriano Anholeto, Rodney Alexandre Ferreira Rodrigues, Gervásio Henrique Bechara, Karina Neoob de Carvalho Castro \& Maria Izabel Camargo Mathias (2018) The potential of Acmella oleracea (Jambu) extract in the control of semi-engorged Rhipicephalus sanguineus (Latreille, 1806) (Acari: Ixodidae) female ticks, International Journal of Acarology, 44:4-5, 192-197, DOI: 10.1080/01647954.2018.1472637

To link to this article: https://doi.org/10.1080/01647954.2018.1472637

曲 Published online: 04 Jun 2018.

Submit your article to this journal $[\pi$

山 Article views: 37

View Crossmark data \lceil 


\title{
The potential of Acmella oleracea (Jambu) extract in the control of semi-engorged Rhipicephalus sanguineus (Latreille, 1806) (Acari: Ixodidae) female ticks
}

\author{
Patrícia Rosa de Oliveira ${ }^{a}$, Luis Adriano Anholeto ${ }^{a}$, Rodney Alexandre Ferreira Rodrigues ${ }^{b}$, \\ Gervásio Henrique Becharac, Karina Neoob de Carvalho Castro ${ }^{d}$ and Maria Izabel Camargo Mathias ${ }^{a}$
}

aDepartment of Biology, Institute of Biosciences, São Paulo State University-UNESP, Rio Claro, Brazil; bivision of Chemistry of Natural Products, CPQBA/UNICAMP, Paulínia, Brazil; 'Graduate Program in Animal Science, School of Agricultural Science and Veterinary Medicine, The Pontificia Universidade Catolica do Parana - PUCPR, Curitiba, Brazil; ${ }^{d}$ Embrapa Meio-Norte, Parnaíba, Brazil

\begin{abstract}
The present study evaluated the efficacy of Acmella oleracea extract, and the susceptibility of semiengorged $R$. sanguineus females exposed to different concentrations of the extract, with lethal concentration $50 \%\left(\mathrm{LC}_{50}\right)$ and confidence interval 95\%. The ticks were mounted on Petri dishes and immersed in the different concentrations of the extract, distilled water or ethanol $50 \%+$ DMSO $1 \%$ for 5 minutes, dried and kept in BOD incubator for 7 days. The results showed the daily mortality rate among semi-engorged $R$. sanguineus females at different concentrations of the extract. The mortality data obtained in bioassay 2 were subjected to Probit analysis, through which a LC $_{50}$ of $24,883 \mathrm{mg} / \mathrm{ml}$ (limits: 22,331 to $28,003 \mathrm{mg} / \mathrm{ml}$ ) was determined, at a $95 \%$ confidence interval. Thus, this study demonstrated the sensitivity and susceptibility of semi-engorged $R$. sanguineus females to Acmella oleracea extract. The acaricidal potential was effective as from the application of the extract at the concentration of $12.5 \mathrm{mg} / \mathrm{ml}$ and was dose-dependent. i.e., higher mortality rates were observed as the concentration increased, with $\mathrm{LC}_{50}$ of $24,883 \mathrm{mg} / \mathrm{ml}$ reaching $100 \%$ at the concentration of $100 \mathrm{mg} / \mathrm{ml}$ in $24 \mathrm{~h}$
\end{abstract}

\section{ARTICLE HISTORY}

Received 26 December 2017 Accepted 1 April 2018 Published online to 4 June 2018

\section{KEYWORDS}

Extract; Rhipicephalus sanguineus; tick; natural compound; potential

\section{Introduction}

Rhipicephalus sanguineus Latreille, 1806 (Acari, Ixodidae) ticks, with widespread distribution in Brazil and across the globe, have considerable importance for human and animal health. These ectoparasites are pathogen vectors for the hosts, also affecting human populations (Demma et al. 2005; Dantas-Torres 2008, 2010; Eremeeva et al. 2011).

$R$. sanguineus control is mostly performed through the application of chemical acaricides to the environment and/or directly to the dogs (Labruna and Pereira 2001; Dantas-Torres et al. 2006; de Oliveira et al. 2008, 2009). However, these substances, which are frequently misused, and their indiscriminate application, lead to the selection of resistant populations (Labarthe 1994; Leal et al. 2003). The literature has reported $R$. sanguineus resistance to acaricides commercialized around the globe (Miller et al. 2001; Burridge et al. 2003; Estrada-Pena 2005; Miranda et al. 2007).

Considering the risks resulting from environmental contamination caused by indiscriminate use of chemical products and the resistance developed by ectoparasites, natural compounds, i.e. extracts from plants, with acaricidal potential emerge as a highly promising control strategy (Miranda et al. 2007; Vendramini et al. 2012).

In this sense, plants from the family Meliaceae, including the species Melia (Oelrichs et al. 1983), Trichilia, Toona, Aglaia and Azadirachta indica (Martinez 2002), among others, have been proven to be efficient against Arthropoda. Additionally, these substances degrade quickly, once they are obtained from renewable sources (Martinez 2002).

Acmella oleracea, popularly known as Jambu, is a plant of the family Asteraceae, typical from the north region of the Brazil, with hot and humid climate. It is used as condiment, as an ingredient in cosmetic composition and in popular medicine, with bactericidal (Pessini et al. 2003), fungistatic and fungicidal (Fabry et al. 1996) properties, in addition to presenting ovicidal and larvicidal activity against Aedes aegypti (dengue), Anopheles culicifacies (malaria) and Culex quiquefaciatus (malaria) (Saraf and Dixit 2002; Simas et al. 2013) mosquitoes. Recent studies have demonstrated the acaricidal properties of the extracts obtained from $A$. oleracea against Rhipicephalus $B$. microplus, confirming its high efficiency against larvae and engorged females (Castro et al. 2014).

Acmella oleracea is a small, semi-erect herbaceous plant, measuring 30-60 cm tall, with cylindrical fleshy stem and decumbent branches. The primary root has axial growth, with abundant lateral and adventitious roots in the stems and branches in contact with the soil. Its leaves are simple, with broadly ovate blade, and sparse hair on both surface. The flowers are small and yellow, arranged in globose chapters, with approximately $1 \mathrm{~cm}$ of diameter. The fruit is a very small achene with dark grey pericarp, partially surrounded by membranous paleas (Favoreto and Gilbert 2010). The plant blossoms all year long in the tropics and in early summer in temperate regions (Hind and Biggs 2003).

The main biological effects of Acmella oleracea are attributed to the spilanthol or affinin [N-2-Methylpropyl)-2,6,8-decatrienamide or $\mathrm{N}$-isobutyl-2E,6Z,8E-decatrienamide)], an aliphatic alkamide with molecular formula $\mathrm{C} 14 \mathrm{H} 23 \mathrm{NO}$, described as a yellowish viscous oil, obtained for the first time by Gerber in 1903 (Ramsewak 1999).

The evaluation of the efficacy of a chemical is usually performed through in vitro bioassays, which are relatively simple, inexpensive and require little equipment (Scott 1995).

Thus, the present study aimed to verify the efficacy of Acmella oleracea extract and the level of susceptibility of semi-engorged $R$. sanguineus adult females exposed to different concentrations through in vitro bioassay protocol (AIT), monitored on a daily basis, determining the $\mathrm{LC}_{50}$ (lethal concentration 50\%) with a $95 \%$ confidence interval. 


\section{Material and methods}

\subsection{Study site}

The present study was conducted in the facilities of the Histology Laboratory of the Biology Department I.B. - UNESP - Campus Rio Claro, SP, Brazil. The tick colonies were kept in this institution by the Brazilian Centre of Studies on Ticks Morphology (BCSTM), under the coordination of Prof. Dr. Maria Izabel Camargo Mathias.

\subsection{Chemical substance}

\subsubsection{Natural extract of Acmella oleracea}

The crude ethanolic extract from the aerial parts (flowers, leaves and stem) of $A$. oleracea was provided by the Chemical Laboratory of Natural Products from the Pluridisciplinary Center of Chemical, Biological and Agricultural Research (CPQBA) University of Campinas (UNICAMP), Campinas, SP, Brazil, under the supervision of Dr. Rodney Alexandre Ferreira Rodrigues and support from postgraduate student Lais Thiemi Yamane.

The plants were cultivated in the experimental field of CPQBA/ UNICAMP, located in Paulinia, SP, Brazil (geographical coordinates $\left.-22^{\circ} 47 \rrbracket 52 \rrbracket S,-47^{\circ} 6 \rrbracket 49 \bigotimes\right)$. The seeds were provided by the company Centroflora (Botucatu, SP, Brazil) and the aerial parts flowers, leaves and stem - were collected in April 2015. The plant was identified by Dr. John F. Pruski of Missouri Botanical Garden (USA), and a voucher specimen was deposited in CPQBA/ UNICAMP Herbarium, Campinas, SP, Brazil, number 181,452. License for genetic testing (CGEN) number is 010577/2014-9.

\subsubsection{Drying and milling the plant material}

After collected, the aerial parts (flowers, leaves and stems) of $A$. oleracea were dried at $40^{\circ} \mathrm{C}$ under forced ventilation for $48 \mathrm{~h}$ until constant weight (Rodrigues et al. 2006), milled with a knife mill and passed through a 48-mesh sieve $-0.297 \mathrm{~mm}$. The resulting material was placed in polypropylene-coated Kraft bags and kept in freezer at $-20^{\circ} \mathrm{C}$.

\subsubsection{Preparing the crude ethanolic extract of Acmella oleracea}

\section{(L.) R. L. Jansen}

The extraction was performed through mechanical stirring in a stainless tank, at room temperature, using ethanol $96^{\circ} \mathrm{GL}$ (proportion 1:5 plant/solvent) for $1.5 \mathrm{~h}$. The material was filtered three times to separate the residues (Rodrigues et al. 2006). The resulting crude extract was filtered, homogenized and concentrated under vacuum in rotary evaporator at $40^{\circ} \mathrm{C}$, lyophilized until a constant weight was attained, stored in amber flasks and kept in freezer until use.

\subsubsection{Analytical monitoring of spilanthol}

The quantification of spilanthol in the extract was performed using a gas chromatograph coupled with a mass detector (GCMS, Agilent $\AA 5890$ Series II mass selective detector Agilent $\AA$ $5970 \mathrm{El} 70 \mathrm{eV}$ ) equipped with a fused silica column WCOT, HP5MS, Agilent ${ }^{\circledR}$, dimensions $30 \mathrm{~m} \times 0.25 \mathrm{~mm} \times 0.25 \mathrm{~m}$. The analysis conditions were: injector temperature: $220^{\circ} \mathrm{C}$; detector temperature: $250^{\circ} \mathrm{C}$, temperature programme: $60-240^{\circ} \mathrm{C}\left(3^{\circ} \mathrm{C} / \mathrm{min}\right)$, sample injection using split mode at 1:40 ratio, Helium gas was used as carrier at 0.7 bar, $1 \mathrm{~mL} / \mathrm{min}$.

\subsection{Rhipicephalus sanguineus ticks (Latreille, 1806)}

R. sanguineus semi-engorged females, weighing $27 \mathrm{mg}$ on average (about 5 days of feeding) were used throughout the experiment. The ticks were provided by the Animal Facility of the Department of Biology - UNESP, Rio Claro campus/São Paulo, Brazil, where the colony is maintained under controlled conditions $\left(28^{\circ} \mathrm{C}, 85 \%\right.$ humidity, and 12-h photoperiod) in a Biological Oxygen Demand (BOD) incubator. Unfed R. sanguineus couples (25 couple/ infestation) were allowed to feed on naive New Zealand white rabbits following Bechara et al. (1995) until reaching the semiengorged stage. The semi-engorged stage of the females was chosen due to the high parasitic efficiency in this phase.

\subsection{Hosts}

New Zealand white rabbits, weighing between 3 and $3.5 \mathrm{~kg}$, were used as hosts. Rabbits were obtained from the Animal Facility of UNESP - Campus Botucatu/São Paulo - Brazil and housed in the Animal Facility of UNESP - Rio Claro Campus/São Paulo - Brazil. The animals had not had prior contact with ticks or acaricides, and were kept under controlled conditions. During the entire experiment, the rabbits were maintained in cages, receiving water and commercial food ad libitum.

This study was approved by the Ethics Committee for Animal Experimentation of UNESP/SP/Brazil, protocol no. 6334/2014.

\subsection{Extract concentration}

The initial concentration of the extract was established according to Castro et al. (2014). The concentrations used in bioassay 1 $(1.6 \mathrm{mg} / \mathrm{ml}, 3.1 \mathrm{mg} / \mathrm{ml}, 6.2 \mathrm{mg} / \mathrm{ml}, 12.5 \mathrm{mg} / \mathrm{ml}, 25 \mathrm{mg} / \mathrm{ml}$, $50 \mathrm{mg} / \mathrm{ml}$ and $100 \mathrm{mg} / \mathrm{ml}$ ) were obtained by diluting the extract in a solution of $50 \%$ ethanol $+1 \%$ DMSO. All concentrations were stored and labelled in Petri dishes until use. Each treatment was performed in duplicate.

After determining the mortality interval $(12.5-50 \mathrm{mg} / \mathrm{ml})$ in bioassay 1 , new dilutions were performed in order to obtain other concentrations within this mortality interval: $14.3 \mathrm{mg} / \mathrm{ml}$, $16.6 \mathrm{mg} / \mathrm{ml}, 20 \mathrm{mg} / \mathrm{ml}, 25 \mathrm{mg} / \mathrm{ml}, 33.3 \mathrm{mg} / \mathrm{ml}$ and $40 \mathrm{mg} / \mathrm{ml}$. These concentrations were used in bioassay 2 .

\subsection{Bioassay 1}

Twenty semi-engorged $R$. sanguineus females (10 ticks per Petri dish) were used for each concentration of extract and control groups 1 and 2 . The ticks were rinsed in a sieve under running tap water, dried with soft paper towel, mounted on labelled Petri dishes and immersed in each concentration for $5 \mathrm{~min}$. For control groups 1 and 2, the females were immersed in distilled water and in a solution of $50 \%$ ethanol and $1 \%$ DMSO for $5 \mathrm{~min}$, respectively. Then, the ticks were dried, mounted on Petri dishes and kept in BOD incubator for 7 days, because acaricides usually act slowly in the physiology of ticks, and their effects are only visible after this period Roma et al. (2009).

Mortality rates and the effects of extract were monitored daily. The mortality interval was determined by observing the behaviour of ticks up to the 7th day of treatment. Ticks were considered dead when not moving their legs when touched with the tip of a paintbrush.

\subsection{Bioassay 2}

The $R$. sanguineus females were rinsed in a sieve under running tap water and dried with soft absorbent paper. The immersion procedure is the same described for bioassay 1 . One hundred and sixty semi-engorged females (eight treatment groups with 20 females each - 10 individuals on each Petri dish) were mounted on labelled Petri dishes and immersed in each concentration of the extract for $5 \mathrm{~min}$.

The control group 1 and 2 ticks were immersed in distilled water and in $50 \%$ ethanol and $1 \%$ DMSO for the same period. Ticks were dried in absorbent paper, mounted on labelled Petri dishes and kept in BOD incubator $\left(28 \pm 1{ }^{\circ} \mathrm{C}, 80 \%\right.$ humidity and $12 \mathrm{~h}$ photoperiod) for 7 days.

Posteriorly, the level of susceptibility of the females to each concentration of the bioassay 2 was analysed, and daily mortality for each concentration was monitored. Mortality criterion was the inability to move the locomotor appendages. 
Table 1. Percentage of dead of semi-engorged females Rhipicephalus sanguineus ticks exposed to different concentrations of the extract of Acmella oleracea Bioassay 1.

\begin{tabular}{|c|c|c|c|c|c|c|c|c|}
\hline & & \multicolumn{7}{|c|}{ Percentage of dead ticks/days of treatment } \\
\hline & & 1st day & 2nd day & 3rd day & 4th day & 5th day & 6th day & 7th day \\
\hline \multirow[t]{9}{*}{ Concentration of Acmella olerace (mg/ml) } & Control 1 & 0 & 0 & 0 & 0 & 0 & 0 & 0 \\
\hline & Control 2 & 0 & 0 & 0 & 0 & 0 & 0 & 0 \\
\hline & $1.6 \mathrm{mg} / \mathrm{ml}$ & 0 & 0 & 0 & 0 & 0 & 0 & 0 \\
\hline & $3.1 \mathrm{mg} / \mathrm{ml}$ & 0 & 0 & 0 & 0 & 0 & 0 & 0 \\
\hline & $6.2 \mathrm{mg} / \mathrm{ml}$ & 0 & 0 & 0 & 0 & 0 & 0 & 0 \\
\hline & $12.5 \mathrm{mg} / \mathrm{ml}$ & 0 & 0 & 0 & 0 & 5 & 5 & 10 \\
\hline & $25 \mathrm{mg} / \mathrm{ml}$ & 10 & 15 & 20 & 20 & 30 & 40 & 50 \\
\hline & $50 \mathrm{mg} / \mathrm{ml}$ & 15 & 20 & 25 & 35 & 55 & 60 & 90 \\
\hline & $100 \mathrm{mg} / \mathrm{ml}$ & 100 & 100 & 100 & 100 & 100 & 100 & 100 \\
\hline
\end{tabular}

Table 2. Percentage of dead of semi-engorged females Rhipicephalus sanguineus ticks exposed to different concentrations of the extract of Acmella oleracea Bioassay 2.

\begin{tabular}{|c|c|c|c|c|c|c|c|c|}
\hline & & \multicolumn{7}{|c|}{ Percentage of dead ticks/days of treatment } \\
\hline & & 1st day & 2nd day & 3rd day & 4th day & 5th day & 6th day & 7th day \\
\hline \multirow[t]{8}{*}{ Concentration of Acmella oleracea $(\mathrm{mg} / \mathrm{ml})$} & Control 1 & 0 & 0 & 0 & 0 & 0 & 0 & 0 \\
\hline & Control 2 & 0 & 0 & 0 & 0 & 0 & 0 & 0 \\
\hline & $14.3 \mathrm{mg} / \mathrm{ml}$ & 0 & 0 & 0 & 0 & 0 & 0 & 5 \\
\hline & $16.6 \mathrm{mg} / \mathrm{ml}$ & 0 & 0 & 0 & 0 & 5 & 10 & 20 \\
\hline & $20 \mathrm{mg} / \mathrm{ml}$ & 0 & 5 & 10 & 10 & 15 & 30 & 50 \\
\hline & $25 \mathrm{mg} / \mathrm{ml}$ & 15 & 15 & 15 & 15 & 35 & 35 & 55 \\
\hline & $33.3 \mathrm{mg} / \mathrm{ml}$ & 5 & 10 & 15 & 15 & 35 & 40 & 65 \\
\hline & $40 \mathrm{mg} / \mathrm{ml}$ & 10 & 20 & 30 & 30 & 40 & 65 & 80 \\
\hline
\end{tabular}

\subsection{Statistical analysis}

The mortality data for the semi-engorged $R$. sanguineus females in bioassay 2 were analysed through one-way analysis of variance (ANOVA) with the application of post hoc Tukey's test, significance levels set at $p<0.05$, using the software Graph-Pad Prism v.6 (GraphPad Software Inc., San Diego, CA, EUA). Lethal concentration $\left(\mathrm{LC}_{50}\right)$ and $95 \%$ confidence interval were calculated through Probit analysis using software BioStat v5.

\section{Results}

The efficacy of the extract from Acmella oleracea against semiengorged $R$. sanguineus females was verified using Drummond et al. (1973) test. In the present study, the results were obtained with the application of 13 different concentrations of this extract, tested in duplicate (Tables 1-3 and Figure 1).

Bioassay 1 showed that the semi-engorged $R$. sanguineus females were not affected by all the extract concentrations used in this study (Table 1).

No mortality was observed following treatment with lower concentrations of the extract $(1.6 \mathrm{mg} / \mathrm{ml}, 3.1 \mathrm{mg} / \mathrm{ml}$ and $6.2 \mathrm{mg} / \mathrm{ml}$ ) throughout the 7-day observation period 7 (Table 1). No morphological or behavioural alterations were recorded for the individuals treated with these concentrations.

At the concentration of $12.5 \mathrm{mg} / \mathrm{ml}$, the extract caused immediate reactions, causing alterations on the living individuals or even death. On the first, second, third and fourth days following treatment, the locomotor capacity decreased. Dead ticks were found 5 days following treatment (Table 1 ).

At higher concentrations $(25 \mathrm{mg} / \mathrm{ml}, 50 \mathrm{mg} / \mathrm{ml}$ and $100 \mathrm{mg} / \mathrm{ml}$ ), a high mortality rate is observed since the first day of treatment. In the concentrations of $25 \mathrm{mg} / \mathrm{ml}$ and $50 \mathrm{mg} / \mathrm{ml}$, the still- alive individuals displayed behavioural alterations, such as progressive decrease in locomotor activity, coordination loss, prostration in inverted position (upside down), stretching of all legs and paralysis. At the highest concentration $(100 \mathrm{mg} / \mathrm{mL})$, the mortality rate was $100 \%$, observed as early as $24 \mathrm{~h}$ of exposure (Table 1 ).

At concentrations, equal or higher than $12.5 \mathrm{mg} / \mathrm{ml}$, a gradual increase in mortality (5-100\%) was observed as the extract concentration increased $(12.5 \mathrm{mg} / \mathrm{ml}, 25 \mathrm{mg} / \mathrm{ml}, 50 \mathrm{mg} / \mathrm{ml}$ and
$100 \mathrm{mg} / \mathrm{ml}$ ) (Figure 1). Likewise, the effects of the extract progressively increased over the observation period. The concentration of $50 \mathrm{mg} / \mathrm{ml}$ caused mortality of $15 \%, 25 \%, 55 \%$ and $90 \%$ on the first, third, fifth and seventh day, respectively (Table 1).

Two mortality peaks (fifth and seventh days) were observed for the females subjected to higher concentrations in bioassay 1 (12.5 mg/ml, $25 \mathrm{mg} / \mathrm{ml}, 50 \mathrm{mg} / \mathrm{ml}$ and $100 \mathrm{mg} / \mathrm{ml}$ ) (Table 1).

The mortality data from bioassay 1, i.e. the number of dead semi-engorged $R$. sanguineus females at each concentration, determined the mortality interval of $12.5 \mathrm{mg} / \mathrm{ml}$ at $50 \mathrm{mg} / \mathrm{ml}$ of extract. Based on this data, new dilutions were performed and the concentrations to be used in bioassay 2 were obtained (Table 2).

The $R$. sanguineus females were sensitive to the extract concentrations tested in bioassay $2(14.3 \mathrm{mg} / \mathrm{ml}, 16.6 \mathrm{mg} / \mathrm{ml}$, $20 \mathrm{mg} / \mathrm{ml}, 25 \mathrm{mg} / \mathrm{ml}, 33 \mathrm{mg} / \mathrm{ml}$ and $40 \mathrm{mg} / \mathrm{ml}$ ). At lower concentrations $(14.3 \mathrm{mg} / \mathrm{ml}$ and $16.6 \mathrm{mg} / \mathrm{ml})$, the mortality rate ranged between $5 \%$ and $20 \%$. The concentrations of $20 \mathrm{mg} / \mathrm{ml}$ and $25 \mathrm{mg} / \mathrm{ml}$ showed $50 \%$ and $55 \%$ of dead individuals, respectively; while in the higher concentrations $(33.3 \mathrm{mg} / \mathrm{ml}$ and $40 \mathrm{mg} / \mathrm{ml}$ ) mortality rates ranged from $60 \%$ to $80 \%$. These data demonstrated that the mortality rates $(5-80 \%)$ gradually increased in higher concentrations of the extract $(14.3 \mathrm{mg} / \mathrm{ml}$, $16.6 \mathrm{mg} / \mathrm{ml}, 20 \mathrm{mg} / \mathrm{ml}, 25 \mathrm{mg} / \mathrm{ml}, 33 \mathrm{mg} / \mathrm{ml}$ and $40 \mathrm{mg} / \mathrm{ml}$ ) (Figure 1, Table 2).

Moreover, in bioassay 2, the extract caused the highest mortality peaks on the fifth, sixth and seventh days of the experiment (Table 2).

All the extract concentrations $(14.3 \mathrm{mg} / \mathrm{ml}, 16.6 \mathrm{mg} / \mathrm{ml}$, $20 \mathrm{mg} / \mathrm{ml}, 25 \mathrm{mg} / \mathrm{ml}, 33 \mathrm{mg} / \mathrm{ml}$ and $40 \mathrm{mg} / \mathrm{ml}$ ) used in bioassay 2 interfered in the behaviour of the individuals tested. Over the 7day period, the ticks presented progressive decrease in locomotor

Table 3. Results of the Probit analysis based on the mortality of semi-engorged females $R$. sanguineus ticks exposed to the extract of Acmella oleracea in Bioassay 2 .

\begin{tabular}{ll}
\hline LC50 & 24.883. limits: 22.331-28.003 \\
\hline Standard error & 0.0283 \\
Degrees of freedom & 4 \\
Heterogeneity & 0.05 \\
Estimation of the confidence interval g (0.95) & 0.1368 \\
\hline
\end{tabular}




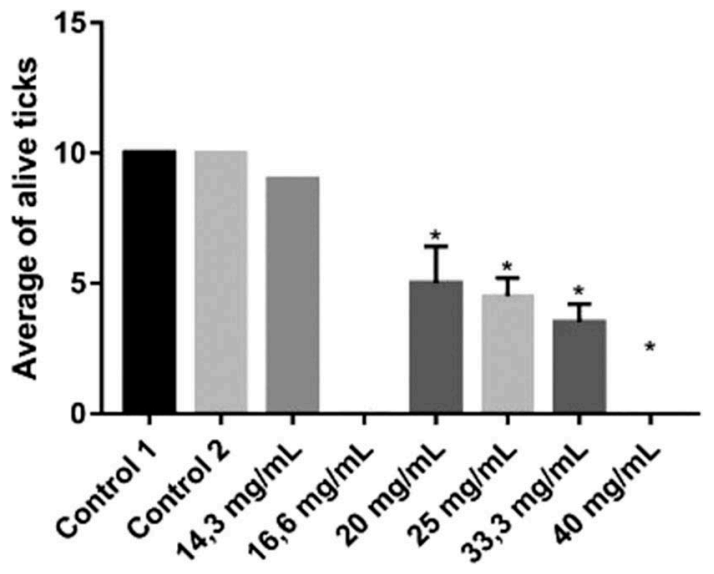

Figure 1. Bioassay 2: Average of live $R$. sanguineus ticks on the 7th day of exposure to different Acmella oleracea extract concentrations. ${ }^{*}$ indicates statistically significant difference $(p<0.05)$. Control $1=$ distilled water; Control $2=50 \%$ ethanol and $1 \%$ DMSO.

capacity, loss of coordination, prostration in inverted position (upside down), stretching of all legs and paralysis.

No morphological alterations were recorded following treatment with lower extract concentrations $(1.6 \mathrm{mg} / \mathrm{ml}, 3.1 \mathrm{mg} / \mathrm{ml}$ and $6.2 \mathrm{mg} / \mathrm{ml}$ ). However, the semi-engorged $R$. sanguineus exposed to the extract at the concentration of $12.5 \mathrm{mg} / \mathrm{ml}$ presented integument dehydration, and this condition evolved as the extract concentration increased (Table 2).

No statistically significant mortality was observed in the individuals belonging to control groups 1 and 2, neither behavioural alterations, nor abnormalities in the morphology, coloration and consistency of the integument over the observation period (7 days) (Figure 1)

Mortality data from bioassay 2 were subjected to Probit analysis to estimate $\mathrm{LC}_{50}$ at $95 \%$ confidence interval, establishing $\mathrm{g}$ (95): $\mathrm{LC}_{50}=24.883 \mathrm{mg} / \mathrm{ml}$ (limits: 22.331-28.003) (Table 3).

\section{Discussion}

Ticks have significant economic importance as ectoparasites and pathogen vectors worldwide, representing one of the biggest obstacles to cattle rearing, causing leather damage, weight loss and reduced milk production. In addition, these ectoparasites are responsible for considerable economic losses associated with medications and medical-veterinary assistance (Walker et al. 2000; Sonenshine and Roe 2014).

The main method to control these ectoparasites is the use of chemical acaricides, which, despite their efficiency, result in the development of resistant populations, in addition to offering risks to other animals and human beings due to the contamination of the environment through the accumulation of toxic residues (Chagas 2004; Dantas-Torres et al. 2006). Therefore, the search for less aggressive and sustainable acaricides is of the utmost importance (de Oliveira et al. 2012).

In this sense, a promising alternative is the use of extracts from plants with acaricidal properties. Several plant species have had their efficacy against ticks tested and the literature reports the success of extracts and other plant substances in controlling different tick species in distinct developmental stages (Chagas 2004).

In studies using R. B. microplus, the essential oils Eucalyptus citriodora and Eucalyptus staigeriana caused 100\% larval mortality at the concentration of $10 \%$ (Chagas et al. 2002). The aqueous extract of Simarouba versicolor inhibited $100 \%$ oviposition at the concentrations of $1.72 \%$ (Pires et al. 2007); and the extract from the roots of $S$. versicolor showed a $75 \%$ acaricidal activity at the concentration of $2.5 \%$ (Catto et al. 2009). Extracts of S. australis leaves applied to $R$. B. microplus females showed efficacy level of $34 \%$ and $66 \%$ when diluted in water and ethanol, respectively (Krawczak et al. 2011).

Considering this information and the fact that $R$. sanguineus ticks have become an important pest, the present study tested the sensitivity and susceptibility of semi-engorged Rhipicephalus sanguineus adult females exposed to different concentrations of Acmella oleracea extract, analysing the efficacy of the extract to control females from this important species.

The research methodology consisted of an in vitro test, where the engorged females were immersed in different formulations with posterior observation and comparison with a control group (Drummond et al. 1973). This is an efficient test, an accurate tool to measure tick sensitivity to the chemical bases of acaricides (Drummond et al. 1973; Scott 1995). The results have immediate practical applicability, directing further research on efficient alternatives to control these ectoparasites (Scott 1995).

The results of bioassays 1 and 2 demonstrated that the semiengorged $R$. sanguineus females were not sensitive to all the concentrations of Acmella oleracea extract tested, once the concentrations of $1.6 \mathrm{mg} / \mathrm{ml}, 3.1 \mathrm{mg} / \mathrm{ml}$ and $6.2 \mathrm{mg} / \mathrm{ml}$ did not cause death or behavioural alterations to the individuals exposed. However, the individuals exposed to the concentration of $12.5 \mathrm{mg} / \mathrm{ml}$ began to have their viability gradually affected, and as of the fifth day, dead individuals were found. At higher concentrations $(14.3 \mathrm{mg} / \mathrm{ml}, 16.6 \mathrm{mg} / \mathrm{ml}, 20 \mathrm{mg} / \mathrm{ml}, 25 \mathrm{mg} / \mathrm{ml}$, $33 \mathrm{mg} / \mathrm{ml}, 40 \mathrm{mg} / \mathrm{ml}, 50 \mathrm{mg} / \mathrm{ml}$ and $100 \mathrm{mg} / \mathrm{ml}$ ), significant mortality was observed and the individuals showed immediate reactions, such as the progressive decrease of locomotor capacity, coordination loss, prostration in inverted position (upside down), stretching of all legs and paralysis. These data indicate that the reduction in the viability of the semi-engorged $R$. sanguineus females was proportional to the extract concentration increase. Similar results were obtained by Castro et al. (2014) for Rhipicephalus B. microplus and by Anholeto et al. (2017) for Amblyomma cajennense.

With specific regard to the concentration of $100 \mathrm{mg} / \mathrm{ml}, 100 \%$ mortality was observed as early as $24 \mathrm{~h}$ following exposure, demonstrating the high efficacy and acaricidal potential of Acmella oleracea extracts. Castro et al. (2014) studied R. B. microplus ticks and reported that the concentration of $1.6 \mathrm{mg} / \mathrm{ml}$ of the hexane extract from Acmella oleracea caused $93 \%$ of larval mortality and the concentrations of $79.7 \mathrm{mg} / \mathrm{ml}$ caused the death of $50 \%$ of engorged females.

The biological activities of $A$. oleracea have been attributed to secondary metabolites, such as spilanthol, an $\mathrm{N}$-alkilamide (Ramsewak 1999). Saraf and Dixit (2002) isolated spilanthol from Acmella olareacea extract and tested it on Culex and Anopheles larvae and pupae, finding $100 \%$ larval mortality for both species $24 \mathrm{~h}$ following exposure to the extract at the concentration of 7.5 ppm. Ramsewak (1999) demonstrated the high insecticidal activity of spilanthol against larvae of Aedes mosquitoes.

In the present study, the efficacy of Acmella oleracea extract was influenced by the exposure time. At the concentration of $20 \mathrm{mg} / \mathrm{ml}, 5 \%, 10 \%, 15 \%, 30 \%$ and $50 \%$ mortality was observed 2 , $3,5,6$ and 7 days following treatment, respectively. At the concentration of $25 \mathrm{mg} / \mathrm{ml}, 15 \%$ mortality was observed on the first days following treatment, $35 \%$ after 5 days, and $55 \%$ after 7 days. The concentration of $33 \mathrm{mg} / \mathrm{ml}$ caused $5 \%, 10 \%, 15 \%, 35 \%, 40 \%$ and $55 \%$ mortality was observed $1,2,3,5,6$ and 7 days following treatment, respectively. At the concentration of $40 \mathrm{mg} / \mathrm{ml}, 10 \%$, $20 \%, 30 \%, 40 \%, 65 \%$ and $80 \%$ mortality was observed 1, 2, 3, 5, 6 and 7 days following exposure, respectively. The concentration of $50 \mathrm{mg} / \mathrm{ml}$ of the extract caused $15 \%, 25 \%, 55 \%$ and $90 \%$ mortality $1,3,5$ and 7 days following treatment, respectively. These data indicate that the highest mortality peaks occurred on the fifth and seventh days, when Acmella oleracea extract presented maximum efficacy. This information is critical for a better comprehension on the plant action against these ectoparasites, serving as a 
basis for the development of new acaricidal products or the application of integrated control, associating this chemical with other methods, aiming to reduce the amount of synthetic chemical acaricides used. Similar data were found by Cruz et al. (2016), who observed gradual increase in mortality for R. B. microplus and Dermacentor nitens treated with Acmella oleracea extract.

No mortality, morphological or behavioural alterations were recorded for control groups 1 and 2 throughout the observation period (7 days).

These results demonstrated the acaricidal effect of the extract obtained from Acmella oleracea; however, further studies are needed to clarify the action mechanism of this natural compound against arthropods. It is widely reported in the literature that the synthetic chemical acaricides act on specific targets in the nervous system (neurotoxic) or on the chitin biochemical process (Cruz et al. 2016).

Broglio-Micheletti et al. (2009) developed studies using R. B. microplus and demonstrated the higher level of efficacy of the jambu extract in comparison with other plants, such as Azadirachta indica (neem) and Cymbopogon citratus (lemon grass), once it was able to cause mortality of the female ticks on the first days following treatment and significantly decreased oviposition.

The results of bioassay 2 , which analysed the efficacy of the Acmella oleracea extract on semi-engorged $R$. sanguineus females were subjected to Probit analysis, with $\mathrm{LC}_{50}$ and $95 \%$ confidence intervals (superior and inferior limits), $g$ (0.95): $\mathrm{LC}_{50}=24.883 \mathrm{mg} / \mathrm{ml}$ (limits: 22.331-28.003). This $\mathrm{LC}_{50}$ of the extract of $24.883 \mathrm{mg} / \mathrm{ml}$ is very low and close to the $L_{50}$ of other renowned synthetic chemical acaricides such as fipronil (de Oliveira et al. 2011), which demonstrates the high efficacy of the extract to control pests, i.e. a small amount of the chemical is able to cause $50 \%$ mortality of the exposed individuals.

\section{Conclusion}

Therefore, the present study demonstrated the sensitivity and susceptibility of semi-engorged $R$. sanguineus female ticks to the extract of Acmella oleracea. The potential acaricidal effect started at the concentration of $12.5 \mathrm{mg} / \mathrm{ml}$. Mortality rate increased in higher concentrations of the extract, with $\mathrm{LC}_{50}$ of $24.883 \mathrm{mg} / \mathrm{ml}$, reaching $100 \%$ for the concentration of $100 \mathrm{mg} / \mathrm{ml}$ in $24 \mathrm{~h}$, i.e. the effects were dose-dependent. It is important to emphasize that, although lower concentrations of the Acmella oleracea extract were sometimes unable to cause death, they caused adverse effects (damages or losses) such as interference in the process of blood intake by hindering the process of fixation to the host, and/or decrease in growth and/or development due to interference in nutrition.

Considering the global appeal for environmental preservation and the promising results regarding the control of Rhipicephalus sanguineus ticks, further studies on the use of Acmella oleracea as a safe and sustainable alternative to control these ectoparasites should be stimulated.

\section{Disclosure statement}

No potential conflict of interest was reported by the authors.

\section{Funding}

We would like to thank to CAPES for financial support and CNPQ academic career research fellowship to G.H. Bechara and M.I. Camargo-Mathias.

\section{References}

Anholeto LA, de Oliveira PR, Rodrigues RAF, Spindola CDS, Labruna MB, Pizano MA, Castro KNDC, Camargo-Mathias MI.
2017. Potential action of extract of Acmella oleracea (L.) R.K. Jansen to control Amblyomma cajennense (Fabricius, 1787) (Acari: Ixodidae) ticks. Ticks Tick Borne Diseases 8:65-72.

Bechara GH, Ferreira BR, Garcia MV. 1995. Rhipicephalus sanguineus tick in Brazil: feeding and reproductive aspects under laboratorial conditions. Brazilian Journal Veterinary Parasitology 4:61-66.

Broglio-Micheletti SMF, Valente ECN, de Souza LA, Dias NDS, de Araújo AMN. 2009. Extratos de plantas no controle de Rhipicephalus (Boophilus) microplus (Canestrini, 1887) (Acari: Ixodidae) em laboratório. Reviews Bras Parasitology Veterinary 18:44-48.

Burridge MJ, Simmons LA, Allan SA. 2003. Efficacy of acaricides for control of four tick species of agricultural and public health significance in the United States. Journal Agricultural Urban Entomological 20:207-219.

Castro KNC, Lima DF, Vasconcelos LC, Leite JRSA, Santos RC, Paz Neto AA, Costa-Júnior LM. 2014. Acaricide activity in vitro of Acmella oleracea against Rhipicephalus microplus. Parasitology Research 113:3697-3701.

Catto JB, Bianchin I, Saito ML. 2009. Efeito acaricida in vitro de extratos de plantas do Pantanal no carrapato de bovinos, Rhipicephalus (Boophilus) microplus. Campo Grande 26:1980-6841.

Chagas A. 2004. Controle de parasitas utilizando extratos vegetais. In: XIII Congresso Brasileiro de Parasitologia Veterinária \& I Simpósio Latino-Americano de Ricketisioses. Revista Brasileira de Parasitologia Veterinária; Ouro Preto. p. 156-160.

Chagas ADS, Passos WM, Prates HT, Leite RC, Furlong J, Fortes ICP. 2002. Efeito acaricida de óleos essenciais e concentrados emulsionáveis de Eucalyptus spp em Boophilus microplus. Brazilian Journal Veterinary Researcher Animals Sciences 39:247-253.

Cruz PB, Barbosa AF, Zeringóta $\mathrm{V}$, Melo D, Novato T, Fidelis QC, Fabri RL, de Carvalho MG, Sabaa-Srur AU, Daemon E, et al. 2016. Acaricidal activity of methanol extract of Acmella oleracea L. (Asteraceae) and spilanthol on Rhipicephalus microplus (Acari: Ixodidae) and Dermacentor nitens (Acari: Ixodidae). Veterinary Parasitology 228:137-143.

Dantas-Torres F. 2008. The brown dog tick, Rhipicephalus sanguineus (Latreille, 1806) (Acari: Ixodidae): From taxonomy to control. Veterinary Parasitology 152:173-185.

Dantas-Torres F. 2010. Biology and ecology of the brown dog tick, Rhipicephalus sanguineus. Parasites \& Vectors 3:26.

Dantas-Torres F, Figueredo LA, Brandão-Filho SP. 2006. Rhipicephalus sanguineus (Acari: Ixodidae), the brown dog tick, parasitizing humans in Brazil. Revista da Sociedade Brasileira de Medicina Tropical 39:64-67.

Demma LJ, Traeger MS, Nicholson WL, Paddock CD, Blau DM, Eremeeva ME, Dasch GA, Levin ML, Singleton J, Zaki SR, et al. 2005. Rocky mountain spotted fever from an unexpected tick vector in Arizona. The New England Journal of Medicine 353:587-594.

Drummond RO, Ernst SE, Trevino JL, Gladney WJ, Graham OH. 1973. Boophilus annulatus and B. microplus: laboratory tests of insecticides. Journal Economics Entomological 66:130-133.

Eremeeva ME, Zambrano ML, Anaya L, Beati L, Karpathy SE, Santos-Silva MM, Salceda B, MacBeth D, Olguin H, Dasch GA, et al. 2011. Rickettsia rickettsii in Rhipicephalus ticks, Mexicali, Mexico. Journal of Medical Entomology 48:418-421.

Estrada-Pena A. 2005. Etude de la résistance de la tique brune du chien, Rhipicephalus sanguineus aux acaricides. Reviews Medica Veterinary (Toulouse) 156:67-69.

Fabry W, Okemo P, Ansorg R. 1996. Fungistatic and fungicidal activity of east African medicinal plants. Mycoses 39:67-70.

Favoreto R, Gilbert B. 2010. Estado da arte/state of the art Acmella oleracea (L.) R. K. Jansen (Asteraceae). Jambu Reviews Fitos 5:83-91.

Hind N, Biggs N. 2003. Plate 460. Acmella oleracea compositae. Curtis's Botanical Magazine 20:31-39. 
Krawczak FDS, Buzatti A, Pivoto FL, Sangioni LA, Vogel FS, Botton SDA, Zanetti GD, Manfron MP. 2011. Acaricide activity of leaves extracts of Sambucus australis Schltdl. (Caprifoliaceae) at $2 \%$ on engorged females of Rhipicephalus (Boophilus) microplus. Ciência Rural 41:2159-2163.

Labarthe NV. 1994. Biological control of tick populations: review and reflections. Cadernos de Saude Publica 10:47-52.

Labruna M, Pereira M. 2001. Carrapato em Cães no Brasil. Clínica Veterinária 30:24-32.

Leal AT, Freitas DR, Vaz Junior ID. 2003. Perspectivas para o controle do carrapato bovino. Acta Sciences Veterinary 31:1-11.

Martinez SS. 2002. O Nim - Azadirachta indica: natureza, usos múltiplos. Londrina: IAPAR.

Miller RJ, George JE, Guerrero F, Carpenter L, Welch JB. 2001. Characterization of acaricide resistance in Rhipicephalus sanguineus (latreille) (Acari: Ixodidae) collected from the Corozal Army Veterinary Quarantine Center, Panama. Journal of Medical Entomology 38:298-302.

Miranda L, Borges F, Soares SF, Nogueira I. 2007. Resistência acaricida em larvas de Rhipicephalus sanguineus (Acari: Ixodidae) de Goiânia-GO, Brasil. Reviews Patol Tropical 36:87-95.

Oelrichs PB, Hill MW, Vallely PJ, MacLeod JK, Molinski TF. 1983. Toxic tetranortriterpenes of the fruit of Melia azedarach. Phytochemistry 22:531-534.

Oliveira PR, Bechara GH, Camargo-Mathias MI. 2008. Evaluation of cytotoxic effects of fipronil on ovaries of semi-engorged Rhipicephalus sanguineus (Latreille, 1806) (Acari: Ixodidae) tick female. Food and Chemical Toxicology : an International Journal Published for the British Industrial Biological Research Association 46:2459-2465.

Oliveira PR, Bechara GH, Denardi SE, Pizano MA, Mathias MIC. 2011. Toxicity effect of the acaricide fipronil in semi-engorged females of the tick Rhipicephalus sanguineus (Latreille, 1806) (Acari: Ixodidae): preliminary determination of the minimum lethal concentration and LC(50). Experimental Parasitology 127:418-422.

Oliveira PR, Bechara GH, Morales MAM, Mathias MIC. 2009. Action of the chemical agent fipronil on the reproductive process of semi-engorged females of the tick Rhipicephalus sanguineus (Latreille, 1806) (Acari: Ixodidae). Ultrastructural evaluation of ovary cells. Food Chemical Toxicogical 47:1255-1264.

Oliveira PR, Calligaris IB, Roma GC, Bechara GH, Mathias MIC. 2012. Morphological characterization of the nymphs Rhipicephalus sanguineus ticks (Latreille, 1806) (Acari: Ixodidae). Description of the testes, integument, Malpighian tubules, and midgut on the detachment day. Microscopy Researcher Technical 75:727-736.

Pessini GL, Holetz FB, Sanches NR, Cortez DAG, Dias Filho BP, Nakamura CV. 2003. Avaliação da atividade antibacteriana e antifúngica de extratos de plantas utilizados na medicina popular. Reviews Bras Farmacogn 13:21-24.

Pires JE, Fernandes RM, Fernandes MZLCM, Viana GEN, Dourado $\mathrm{JCL}$, Sousa SAA. 2007. Determinação da concentração inibitória média $(\mathrm{Cl} 50)$ do extrato aquoso de Simarouba versicolor, St. Hill sobre a ovipostura do carrapato bovino (Boophilus microplus Canestrine, 1887). Revista Brasileira de Plantas Medicinais 9:23-26.

Ramsewak R. 1999. Bioactive N-isobutylamides from the flower buds of Spilanthes acmella. Phytochemistry 51:729-732.

Rodrigues RAF, Foglio MA, Boaventura Júnior S, Santos ADS, Rehder VLG. 2006. Otimização do processo de extração e isolamento do antimalárico artemisinina a partir de Artemisia annua L. Quimica Nova 29:368-372.

Roma GC, de Oliveira PR, Pizano MA, Mathias MI. 2009. Determination of $\mathrm{LC}(50)$ of permethrin acaricide in semiengorged females of the tick Rhipicephalus sanguineus (Latreille, 1806) (Acari: Ixodidae). Experimental Parasitology 123:269-272.

Saraf VK, Dixit VK. 2002. Spilanthes acmella Murr.: study on its extract spilanthol as larvicidal compound. Asian Journal Experiments Sciences. 16:9-19.

Scott JA. 1995. The molecular genetics of resistance: resistance as a response to stress. Florida Entomologist 78:399-414.

Simas NK, Dellamora E, Schripsema J, Lage CLS, De O.Filho AM, Wessjohann L, Porzel A, Kuster RM. 2013. Acetylenic 2-phenylethylamides and new isobutylamides from Acmella oleracea (L.) R. K. Jansen, a Brazilian spice with larvicidal activity on Aedes aegypti. Phytochem Letters 6:67-72.

Sonenshine DE, Roe RM. 2014. Biology of ticks. 2nd ed. New York, NY: Oxford University Press.

Vendramini MCR, Mathias MIC, De Faria AU, Furquim KCS, De Souza LP, Bechara GH, Roma GC. 2012. Action of andiroba oil (Carapa guianensis) on Rhipicephalus sanguineus (Latreille, 1806) (Acari: Ixodidae) semi-engorged females: morphophysiological evaluation of reproductive system. Microscopy Research and Technique 75:1745-1754.

Walker JB, Keirans JE, Horak IG. 2000. The genus Rhipicephalus (Acari: Ixodidae). A guide to the brown ticks of the world. London: Cambridge University Press. 